Available online at GSC Online Press Directory

GSC Biological and Pharmaceutical Sciences

e-ISSN: 2581-3250, CODEN (USA): GBPSC2

Journal homepage: https://www.gsconlinepress.com/journals/gscbps

(RESEARCH ARTICLE)

\title{
Examining the effects of adding boric acid at different doses into mixed feed on fattening performance, carcass characteristics, and bone quality of Japanese quails
}

\author{
Ulku Gulcihan Simsek ${ }^{1,}{ }^{*}$, Sultan Aslan ${ }^{2}$, Nurgul Birben ${ }^{3}$ and Burak Altundal 4 \\ ${ }^{1}$ Department of Animal Science, Faculty of Veterinary Medicine, Firat University, Elazig, Turkey. \\ ${ }^{2}$ Department of Genetic, Faculty of Veterinary Medicine, Dokuz Eylul University, Izmir, Turkey. \\ ${ }^{3}$ Veterinary Control Research Institute of Elazig, Elazig, Turkey. \\ ${ }^{4}$ Faculty of Veterinary Medicine, Firat University, Elazig, Turkey.
}

Publication history: Received on 31 August 2020; revised on 28 September 2020; accepted on 29 September 2020

Article DOI: https://doi.org/10.30574/gscbps.2020.13.1.0284

\begin{abstract}
The aim of this study is to investigate the effects of adding different doses of boric acid (H3BO3) to the mixed feed of Japanese quail (Coturnix coturnix Japonica) on fattening performance, carcass and bone properties. For this purpose, a total of 96 quails aged 15 days were balanced according to their live weight and sex, and 4 trials were randomly divided into groups. Each group is composed of 4 repetitions. Trial groups; the control group (C) given mixed feed, the group with $100 \mathrm{mg} / \mathrm{kg}$ boric acid (BA) added to the feed BA100; $300 \mathrm{mg} / \mathrm{kg}$ boric acid was added to the feed group BA300 and $500 \mathrm{mg} / \mathrm{kg}$ boric acid added to the feed group BA500. Data for the fattening period were followed for 15-43 days. At the end of the experiment, carcass and bone characteristics of 8 quails (two quails from each repeat) from each group were examined. The live weight and live weight gain of the quail was similar among the experimental groups ( $>0.05$ ). Adding boric acid to feed did not affect feed consumption and feed utilization rate $(\mathrm{P}>0.05)$. While the breast rate decreased significantly due to the increasing levels of boric acid addition $(\mathrm{P}<0.01)$, an increase in the back and neck ratio was detected $(\mathrm{P}<0.05)$. The highest thigh ratio was found in BA300 and BA500 groups $(\mathrm{P}<0.05)$. Carcass yield, wing and liver rates were similar between the groups $(\mathrm{P}>0.05)$. Tibia and femur weights and dimensions were not affected by the addition of boric acid ( $>>0.05)$. The highest femoral ash level was determined in the BA300 group $(\mathrm{P}=0.05)$. The tibia ash level increased from the Control group towards BA300 and was the lowest in the BA500 group $(\mathrm{P}<0.05)$. As a result, while the addition of boric acid to the feed cannot be affected to the fattening performance of quail, its effect on carcass and bone properties has been found significant.
\end{abstract}

Keywords: Boric acid; Performance; Carcass; Bone Quality; Quail

\section{Introduction}

The use of poultry meat, which is important for human health, in human nutrition has gradually increased the importance of poultries such as quail, chicken and turkey, which reach to slaughter weight in a short time, in recent years. This rapid increase in live weight in poultries, brings along the problems related to skeletal system [1].

Boron is the fifth metal in the periodic table and it has been included in Group IIIA based on its chemical and physiological characteristics [2]. Its atomic number is 5 and its melting point is 2300 oC. Boron is not found in nature alone, it is found in combination with the other elements generally named as "borates" in oxygen and salts. More than 250 minerals containing boron have been identified. The most common ones are sodium, calcium or magnesium salts. Boron is an element found rarely in nature [3]. Boric acid is a brilliant and water-soluble acid crystallized in white flakes.

\footnotetext{
${ }^{*}$ Corresponding author: Ulku Gulcihan Simsek

Department of Animal Science, Faculty of Veterinary Medicine, Firat University, Elazig, Turkey.
} 
Many of the minerals contain boric acid but the most important ones are borax, colemanite, ulexite, and kernite in boron industry [3,4]. Boron, which is used in many areas in industry and has many biological effects, is a mineral which should be taken into the body through nutrients.

The biochemical action mechanism of boron element in human and animal tissues is not known exactly but it has been included intensely in various biochemical studies on human and animal metabolism as a nutritive micro element after the 80s. It has been reported that boron has important functions in mineral, lipid and energy metabolism, endocrine system, immune system and brain, increases performance and may be used for preventing osteoporosis, osteoarthritis, and arthritis [5, 6]. In addition, it has been revealed that boron strengthens antioxidant defense system by increasing catalase, superoxide dismutase, and glutathione production in tissues, has an immunostimulant effect, has an antiinflammatory and epithelizing effect by decreasing mRNA expression levels of Bax proteins and suppressing TNF- $\alpha$ production induced by lipopolysaccharide [4, 7], causes increase in steroid hormones (plasma estradiol and testosterone) $[4,7,8]$, and has an antimicrobial character [9]. Boron interacts with calcium, phosphor, vitamin D and magnesium, which are important in bone metabolism, and accumulates in bone in the concentrations based on the consumed amount of boron [10]. It enhances the balance of bone strength by playing an important role in the metabolism of macro minerals, mainly calcium, and decreases the losses caused by bone fractures $[8,11]$. Boric acid compounds is found in different types in carbohydrates (glucose and polysaccharides), nucleotides (adenosine monophosphate and niacinamide adenine dinucleotide) and vitamins (ascorbic acid, pyridoxine, riboflavin). Also, boron element has important functions in brain functions, immune system, cell structure and functions [12]. Due to these important biological effects of boron, its usage opportunities in farming has gained importance day by day.

Japanese quail (Coturnix coturnix Japonica) is a breed commonly raised for its meat and egg. It reaches a live weight of 200-250 g when it is 40-42 day-old and a quail consumes 25-30 g of feed daily. The average feed conversion rate in quails varies between 3 and 4. Extensive quail farming has increased rapidly in recent years due to the biological characteristics of its meat and egg, easy and economic production and its suitability to the taste of the public. It is also good animal model in poultry researches due to the features given above. The attraction of the quail products has caused many studies to be conducted on quail farming in different environmental conditions and that the studies affecting both the amount and the quality of the products have still arouse interest and have led to preservation of its up-to-dateness $[13,14]$. There are various research studies on the use of different forms and doses of boron in the feed of quails and the other poultry species. However, different results have been obtained on the effect of boron on poultry performance and metabolism in these researches $[10,14,15]$. Accordingly, it is thought that there is a need for different studies on the use of different doses and forms of boron compounds as feed supplements.

In this sense, the aim of this planned study was to examine the effects of boric acid added to feed in different doses on the fattening performance, carcass characteristics, and bone quality in Japanese quails.

\section{Material and methods}

\subsection{Ethical approval}

This study was conducted in Elazığ Veterinary Control Institute Poultry Unit. Approval was received from Elazığ Veterinary Control Institute Local Ethics Committee (EVKEM: 2020/01).

\subsection{Experimental design}

A total of 96 Japanese quails (Coturnix coturnix Japonica) were used in the study. The quails were raised in deep litter system for 15 days. Within this period, the quails were fed with feed and water ad libitum in the rooms with the suitable temperature and humidity for their physiology. They were weighed after fifteen days and divided in experimental groups. At the start of the experiment, the experimental groups were balanced in terms of live weight and gender. Sex determination was performed by considering the type of hair growth on breast. In the study, different doses of boric acid (H3BO3, Lot No: 081118108001) were added into the mixed feed (Table 1). 
Table 1 Caracteristics of used boric acid (H3BO3)

\begin{tabular}{|l|l|}
\hline Content & $\mathbf{\%}$ \\
\hline Purity & $>99.5$ \\
\hline Borontrioksit (B203) & $>56.0$ \\
\hline Sulfate (SO4) & $<0.02$ \\
\hline Chloride (Cl) & $<0.001$ \\
\hline Iron (Fe) & $<0.0007$ \\
\hline
\end{tabular}

Experimental groups were formed as follows; the control group (C) for which any addition was applied, the group in which $100 \mathrm{mg} / \mathrm{kg}$ boric acid (BA) was added in feed (BA100), the group in which $300 \mathrm{mg} / \mathrm{kg}$ boric acid was added in feed (BA300) and the group in which $500 \mathrm{mg} / \mathrm{kg}$ boric acid was added in feed (BA500). The quails were raised for 1543 days in the special cages used of quails. The experimental groups were arranged with 6 quails in each repetition and with 4 repetitions and including totally 24 quails in each group. During the experiment, feed and water were given ad libitum. The basal feed used in the study was prepared in accordance with the National Research Council (NRC) standards [16] and presented in Table 2. The nutrient composition of the basal ration was determined based on Association of Official Analytical Chemists (AOAC) [17]. The metabolizable energy content of the ration was predicted using Carpenter and Clegg [18] equation. ME, kcal/kg=53+38 [(crude protein, \%)+(2.25 $\times$ ether extract,\%)+(1.1×starch,\%) + (sugar,\%)] $(1 \mathrm{kcal}=4.19 \mathrm{~kJ})$. During the experiment, live weights $(\mathrm{LW})$ were determined by weekly weighing measurements. Feed was given by weighing daily and the remaining feed was weighed weekly and daily feed intake (FI) was calculated. The daily consumed feed was proportioned to the daily live weight increase (LWG) and the feed conversion rate (FCR) was calculated. As no quail died during the study, the survival ability was assessed as $100 \%$. To perform the carcass analyses at the end of the fattening period (43rd day), 2 quails ( 1 female, 1 male) from each repetition reflecting the repetition average, 8 quails from each group and totally 32 quails were slaughtered in the experimental groups.

Table 2 The content of basal feed and nutrient compound (\%)

\begin{tabular}{|l|l|}
\hline Feed Materials & \% \\
\hline Corn, Yellow & 51.50 \\
\hline Soybean meal, 48\% & 28.00 \\
\hline Corn Gluten, 43\% Hp & 12.00 \\
\hline Wheat Bran, Coarse & 5.00 \\
\hline Vegetable Oil & 0.51 \\
\hline Dicalcium Phosphate & 0.70 \\
\hline Dl-Methionine & 0.01 \\
\hline Limestone & 1.35 \\
\hline L-Lysine Hydrochloride & 0.27 \\
\hline L- Threonine & 0.16 \\
\hline Salt & 0.25 \\
\hline Vitamin-Mineral Mix* & 0.25 \\
\hline Total & $\mathbf{1 0 0 . 0 0}$ \\
\hline Chemical Composition & \\
\hline KM, \% & 89.9 \\
\hline HP, \% & 24.0 \\
\hline
\end{tabular}




\begin{tabular}{|l|l|}
\hline ME, kcal/kg & 2900 \\
\hline $\mathrm{Ca}, \%$ & 0.80 \\
\hline Ash P, \% & 0.30 \\
\hline $\mathrm{Na}, \%$ & 0.13 \\
\hline $\mathrm{Cl}, \%$ & 0.20 \\
\hline Met+Sis, \% & 0.82 \\
\hline Lysine & 1.30 \\
\hline Threonine,\% & 1.03 \\
\hline Tryptophane, \% & 0.28 \\
\hline Linoleic acid, \% & 1.41 \\
\hline HY, \% & 2.48 \\
\hline HK, \% & 5.52 \\
\hline HS, \% & 3.32 \\
\hline Starch, \% & 37.65 \\
\hline Sugar, \% & 3.65 \\
\hline Electrolyte Balance, $\mathrm{mEq} / \mathrm{kg} \mathrm{KM}$ & 223 \\
\hline
\end{tabular}

*Vitamin-mineral premix (For each $1 \mathrm{~kg}$ ):Vitamin A, 12.000 IU; Vitamin D3, 3.300 IU; vitamin E, 20 mg; Vitamin K3, 4 mg; Vitamin B1, 3.0 mg; Vitamin B2, $7.0 \mathrm{mg}$; Vitamin B6, $5.0 \mathrm{mg}$; Vitamin B12, $0.015 \mathrm{mg}$; Niacin, $25.0 \mathrm{mg}$; D-calcium pantothenate, $10.0 \mathrm{mg}$; folic acid, $1.0 \mathrm{mg}$; D-biotin, 0.05 mg; choline chloride, $175 \mathrm{mg}$; manganese, $100 \mathrm{mg}$; iron, $60 \mathrm{mg}$; zinc $60 \mathrm{mg}$; copper, $5 \mathrm{mg}$; cobalt, $0.5 \mathrm{mg}$; iodine, $2 \mathrm{mg}$; selenium, $0.15 \mathrm{mg}$; phytase, 300.

Slaughtering was performed by using decapitation. The slaughtered quails were plucked and after their carcass weights were determined, they were divided into their parts in accordance with Turkish Standards Institution (TSI) standards [19]. Carcass parts and liver were weighed. Hot carcass and liver weights were proportioned to the slaughter weight and the weights of the carcass parts were proportioned to carcass weight and expressed as percentage. After the humerus and tibio-tarsal bones of the left legs of the quails were separated from meat, they were kept at +4 oC for analyses. The tibio-tarsal and humerus bones were weighed by using precision balance. The width of the bones from their exact midpoint and their length from the distance between the longest two points were measured using a digital caliper (Tresna, USA). The bones were burned in muffle furnace (Protherm, Turkey) at 600 oC for 7-8 hours and then ash measurements were performed [20].

\subsection{Data analysis}

Normality analysis was performed for all the data and it was determined that the data had a normal distribution. The difference between mean values of the groups was assessed by using analysis of variance and advance analyses were also evaluated using Tukey HSD test. Windows-compatible SPSS software was used in performing statistical analyses. If it was $\mathrm{P} \leq 0.05$, the effects were assessed to be significant. The data were given as mean \pm standard error [21].

\section{Results}

Table 3 shows the effects of boric acid added at different doses in mixed feed on the fattening performance of the quails. Boric acid added in feed was not effective on the LW of quails in the examined periods, except for the 29th day. The highest $\mathrm{LW}$ of the 29 th day was obtained in BA500 group $(\mathrm{P}<0.05)$. The experimental groups had similar values in terms of the LWG $(\mathrm{P}>0.05)$. The effects of boric acid on the FI and FCR were not determined to be significant $(\mathrm{P}>0.05)$.

When the effects of boric acid at different doses on carcass characteristics were examined (Table 4), it was determined that breast rate decreased significantly depending on dose increase $(\mathrm{P}<0.01)$; whereas, the back and neck rate increased $(\mathrm{P}<0.05)$. The highest thigh rate was determined in BA300 and 500 groups $(\mathrm{P}<0.05)$. The other characteristics (wing rate, liver rate) were found to be similar between the groups $(\mathrm{P}<0.05)$. 
Table 5 shows the effect of boric acid added in mixed feed on the bone characteristics of quails. Tibia and femur weights, width and length values were not affected by addition of boric acid ( $>>0.05)$. Tibia ash level increased from the control group to BA300 and was observed at the lowest level in the BA500 group $(\mathrm{P}<0.05)$. Ash level of femur was also determined at the highest level in BA300 group $(\mathrm{P}=0.05)$.

Table 3 The effect of boric acid added to mixed feed on the fattening performance of Japanese quails.

\begin{tabular}{|c|c|c|c|c|c|}
\hline & Control & BA100 & BA300 & BA500 & P value \\
\hline \multicolumn{6}{|c|}{ Live Weight (LW), g } \\
\hline 15 (baseline) & $45.91 \pm 1.42$ & $45.75 \pm 1.36$ & $45.75 \pm 1.70$ & $45.79 \pm 1.23$ & 1.000 \\
\hline 22 & $68.12 \pm 2.05$ & $70.41 \pm 2.21$ & $72.83 \pm 2.52$ & $73.41 \pm 1.95$ & 0.308 \\
\hline 29 & $121.75 \pm 4.21^{\mathrm{ab}}$ & $112.83 \pm 3.20^{\mathrm{b}}$ & $123.70 \pm 3.52^{\mathrm{ab}}$ & $126.87 \pm 3.09^{a}$ & 0.039 \\
\hline 36 & $165.37 \pm 3.26$ & $158.70 \pm 3.84$ & $167.54 \pm 3.82$ & $169.37 \pm 3.53$ & 0.183 \\
\hline 43 & $194.37 \pm 4.61$ & $197.75 \pm 4.66$ & $203.87 \pm 5.00$ & $202.16 \pm 5.53$ & 0.525 \\
\hline \multicolumn{6}{|c|}{ Live Weight Gain (LWG), g } \\
\hline $15-22$ & $3.17 \pm 0.25$ & $3.55 \pm 0.35$ & $3.86 \pm 0.30$ & $3.94 \pm 0.34$ & 0.339 \\
\hline $23-29$ & $7.66 \pm 0.43$ & $6.09 \pm 0.22$ & $7.26 \pm 0.36$ & $7.63 \pm 0.44$ & 0.059 \\
\hline $30-36$ & $6.23 \pm 0.68$ & $6.27 \pm 0.40$ & $6.26 \pm 0.29$ & $6.07 \pm 0.30$ & 0.987 \\
\hline $37-43$ & $4.14 \pm 0.57$ & $5.63 \pm 0.54$ & $5.19 \pm 0.16$ & $4.68 \pm 0.78$ & 0.318 \\
\hline $15-43$ & $4.94 \pm 0.23$ & $5.03 \pm 0.29$ & $5.27 \pm 0.11$ & $5.21 \pm 0.22$ & 0.720 \\
\hline \multicolumn{6}{|c|}{ Feed intake (FI), g/day/quail } \\
\hline $15-22$ & $16.83 \pm 1.90$ & $17.20 \pm 1.40$ & $16.49 \pm 2.27$ & $15.91 \pm 1.94$ & 0.968 \\
\hline $23-29$ & $21.37 \pm 1.03$ & $20.78 \pm 1.19$ & $18.87 \pm 2.07$ & $17.91 \pm 1.90$ & 0.427 \\
\hline $30-36$ & $18.12 \pm 2.33$ & $20.16 \pm 3.28$ & $22.99 \pm 2.49$ & $23.62 \pm 2.22$ & 0.445 \\
\hline $37-43$ & $17.83 \pm 2.90$ & $21.12 \pm 2.14$ & $20.20 \pm 2.41$ & $15.66 \pm 0.72$ & 0.331 \\
\hline $15-43$ & $18.53 \pm 1.86$ & $19.81 \pm 1.82$ & $19.64 \pm 2.18$ & $18.27 \pm 1.17$ & 0.905 \\
\hline \multicolumn{6}{|c|}{ Feed conversion ratio (FCR), g FC/g LWG } \\
\hline $15-22$ & $5.27 \pm 0.23$ & $4.84 \pm 0.74$ & $4.27 \pm 0.71$ & $4.03 \pm 0.69$ & 0.559 \\
\hline $23-29$ & $2.80 \pm 0.15$ & $3.42 \pm 0.22$ & $2.62 \pm 0.34$ & $2.34 \pm 0.35$ & 0.115 \\
\hline $30-36$ & $2.89 \pm 0.12$ & $3.21 \pm 0.73$ & $3.69 \pm 0.40$ & $3.89 \pm 0.55$ & 0.496 \\
\hline $37-43$ & $4.30 \pm 0.69$ & $3.75 \pm 0.69$ & $3.89 \pm 0.56$ & $3.34 \pm 0.63$ & 0.833 \\
\hline $15-43$ & $3.75 \pm 0.24$ & $3.94 \pm 0.52$ & $3.73 \pm 0.43$ & $3.51 \pm 0.23$ & 0.828 \\
\hline
\end{tabular}

The data were given as mean and standard error. When it was $\mathrm{P} \leq 0.05$, the differences between the mean values were considered as significant. a.b: The differences between the mean values expressed by different letters were significant.

Table 4 The effect of boric acid added into mixed feed on the carcass characteristics of Japanese quails

\begin{tabular}{|l|l|l|l|l|l|}
\hline Characteristics (\%) & Control & BA100 & BA300 & BA500 & P value \\
\hline Carcass yield & $67.61 \pm 1.02$ & $68.33 \pm 0.72$ & $66.66 \pm 2.05$ & $70.44 \pm 1.53$ & 0.302 \\
\hline Breast rate & $39.25 \pm 0.47^{\mathrm{a}}$ & $38.67 \pm 0.76^{\mathrm{ab}}$ & $35.49 \pm 0.93^{\mathrm{b}}$ & $35.49 \pm 1.05^{\mathrm{b}}$ & 0.003 \\
\hline Thigh rate & $36.99 \pm 0.47^{\mathrm{ab}}$ & $36.31 \pm 0.55^{\mathrm{b}}$ & $38.61 \pm 0.45^{\mathrm{a}}$ & $38.55 \pm 0.75^{\mathrm{a}}$ & 0.017 \\
\hline Wing rate & $9.60 \pm 0.22$ & $9.85 \pm 0.44$ & $9.45 \pm 0.19$ & $8.70 \pm 0.32$ & 0.079 \\
\hline Back+neck rate & $14.14 \pm 0.32^{\mathrm{b}}$ & $15.16 \pm 0.89^{\mathrm{ab}}$ & $16.43 \pm 0.80^{\mathrm{ab}}$ & $17.24 \pm 0.81^{\mathrm{a}}$ & 0.033 \\
\hline Liver rate & $2.69 \pm 0.19$ & $3.27 \pm 0.27$ & $2.91 \pm 0.32$ & $2.92 \pm 0.18$ & 0.445 \\
\hline
\end{tabular}

The data were given as mean and standard error. When it was $\mathrm{P} \leq 0.05$, the differences between the mean values were considered to be significant. a.b: The differences between the mean values expressed by different letters were significant. 
Table 5 The effect of boric acid added into mixed feed on the bone characteristics of Japanese quails.

\begin{tabular}{|l|l|l|l|l|l|}
\hline & Control & BA100 & BA300 & BA500 & P value \\
\hline Tibia weight, mg & $68.04 \pm 3.33$ & $71.55 \pm 3.20$ & $70.54 \pm 2.71$ & $76.31 \pm 2.40$ & 0.267 \\
\hline Femur weight, mg & $50.73 \pm 1.76$ & $54.01 \pm 3.37$ & $57.49 \pm 2.11$ & $57.86 \pm 2.14$ & 0.152 \\
\hline Tibia length, mm & $51.94 \pm 0.89$ & $53.47 \pm 0.37$ & $51.86 \pm 0.43$ & $52.28 \pm 0.62$ & 0.250 \\
\hline Tibia width, mm & $2.80 \pm 0.07$ & $3.17 \pm 0.12$ & $3.05 \pm 0.08$ & $3.15 \pm 0.11$ & 0.051 \\
\hline Femur length, mm & $41.77 \pm 0.62$ & $42.95 \pm 0.49$ & $42.35 \pm 0.45$ & $41.84 \pm 0.49$ & 0.365 \\
\hline Femur width, mm & $3.10 \pm 0.05$ & $3.14 \pm 0.11$ & $2.94 \pm 0.07$ & $3.14 \pm 0.10$ & 0.354 \\
\hline Tibia ash level, \% & $39.37 \pm 1.31^{\mathrm{ab}}$ & $40.28 \pm 0.94^{\mathrm{ab}}$ & $41.78 \pm 0.77^{\mathrm{a}}$ & $36.69 \pm 1.07^{\mathrm{b}}$ & 0.015 \\
\hline Femur ash level, \% & $35.00 \pm 1.13^{\mathrm{b}}$ & $39.07 \pm 1.93^{\mathrm{ab}}$ & $41.65 \pm 1.50^{\mathrm{a}}$ & $37.46 \pm 1.90^{\mathrm{ab}}$ & 0.050 \\
\hline
\end{tabular}

The data were given as mean and standard error. When it was $\mathrm{P} \leq 0.05$, the differences between the mean values were considered to be significant. a.b: The differences between the mean values expressed by different letters were significant.

\section{Discussion}

The skeleton and bone integrity problems in poultry as well as problems related to eggshell quality in laying poultry are important economic, welfare and health problems for the poultry industry. For this reason, the role of boron in poultry farming is important in terms of increasing productivity and improving animal welfare. Boron is an important and known feed factor in calcium metabolism reflecting its importance in normal bone development. As it interacts with pyridine, riboflavin, dehydro-ascorbic acid and pyridine nucleotides, its existence and supplement are highly important [22].

As a result of the present study, it was determined that in the quails fed with boric acid addition (100, 300 and 500 $\mathrm{mg} / \mathrm{kg}$ boric acid), the effects of boric acid on their fattening performance such as FI, FCR and LWG were not important. Among other studies, Olgun et al. [23] reported that the addition of calcium (Ca) and boron (Borax Pentahydrate) at different rates in feed of laying chicken did not affect LW, LWG, FCR and egg quality parameters, significantly. Ayasan et al. [24] reported that addition of boric acid in mixed feed in quails did not had any significant effect in FI, egg production, egg shell weight, and egg shape index but addition of $400 \mathrm{ppm}$ boric acid increased cumulative FI. It increased egg weight but it decreased egg thickness compared to the Control group. In another study [25], it was determined that LW decreased in 150 and $300 \mathrm{mg} / \mathrm{kg}$ boron addition compared to those fed by the feed with 0 and $75 \mathrm{mg} / \mathrm{kg}$ boron in 20 weeks old pullets. Similar findings were also found in the study by Waleed and Hayani [15]. They determined that there was a decrease in LW in the Japanese quail fed with the feed containing 50, 75 and $100 \mathrm{mg} / \mathrm{kg}$ boric acid [boric acid $16 \%$ boron (B)] addition and, the use of $100 \mathrm{mg} / \mathrm{kg}$ boric acid caused a significant decrease in FI. Eren et al. [26] found the addition of 10,60,120 and $240 \mathrm{mg} / \mathrm{kg}$ boron into feed decreased LW, FI and FCR of the quails and the hot and cold carcass yield and carcass dry matter level were not affected but the carcass fat and ash levels of male quails increased. Sizmaz et al. [27] reported that boric acid containing 17.5\% boron and ascorbic acid, when used only and together, did not affect LW, FCR, egg weight, shell breaking resistance, egg thickness, egg albumen and yolk rates, haugh unit and yolk weight. However, bone ash and phosphorus (P) level significantly increased in tibia. Eren et al. [28] reported that 0, 5, 10, 50, 100, 200 and $400 \mathrm{mg} / \mathrm{kg}$ boric acid (H3BO3) was added in feed of laying chicken for 8 weeks after 10-day adaptation. In the group with $400 \mathrm{mg} / \mathrm{kg}$ boron addition, LW, FI and egg production decreased and eggs quality parameters changed. Serum Ca, inorganic P and magnesium (Mg) levels also increased. Hakan et al. [29] found that 90 ppm boric acid and $1 \mathrm{~g} / \mathrm{kg}$ humate were added in feed of laying chicken did not have a significant effect on FI, egg weights and production, egg quality parameters (egg thickness, shell breaking resistance and shape index) compared the control group. However, it was determined that boric acid and humate mixture enhanced FCR significantly. Sizmaz et al. [30] stated that boric acid ( $60 \mathrm{mg} / \mathrm{kg}$ feed) and plant extract mixture (Fitococci, F) (0.75 g/ kg feed), when used only or together, did not have a significant effect in terms of FCR, egg weight and yield, egg quality parameters (egg thickness, shell breaking resistance, and shape index) and blood cholesterol levels compared to the control group. FI increased significantly in the group fed by mixture of plant extract and boric acid. Yıldiz et al. [31] determined that the addition of $2.5 \mathrm{~g} / \mathrm{kg}$ of Saccharomyces cerevisiae (yeast) and $60 \mathrm{mg} / \mathrm{kg}$ of boric acid only or together into broiler ration did not have a significant effect on performance, carcass characteristics, blood parameters and tibia ash and boron levels. Kara [32] reported that adding different levels of zinc (0, 50 and $100 \mathrm{mg} / \mathrm{kg})$ and boron (0, 30, 60, 120 and 240 $\mathrm{mg} / \mathrm{kg}$ ) into feed of breeder quails significantly affected average egg weight, egg surface area, shell rate, shell strength, egg specific weight, tibia and femur ash amount (g and \%), femur Ca, P, Mg, potassium (K), sulfur (S), Zinc (Zn), boron 
(B), manganese ( $\mathrm{Mn}$ ) and molybdenum Mo amounts $(\mathrm{mg} / \mathrm{kg})$ during the experimental period and the some biomechanical characteristics of bone. Olgun et al. [33] determined that the addition of 60,120 and $240 \mathrm{mg} / \mathrm{kg}$ boron into feed improved bone characteristics significantly although it decreased eggshell thickness together with the increasing dose. Mizrak et al., [34] stated that 50, 100 and $200 \mathrm{mg} / \mathrm{kg}$ boron into feed at the age of 64 weeks resulted in a lower LW compared to the control group. It was also reported that boron addition did not affect FI, egg production, egg weight, egg mass, and broken and cracked egg incidence. In the study conducted by Wilson and Ruszler [35] to investigate the effects of the boron $(0,50,100,200$ and $400 \mathrm{mg} / \mathrm{kg})$ addition in white leghorn rations revealed that LW, FI, egg weight and egg production decreased in $400 \mathrm{mg} / \mathrm{kg}$ boron addition in feed and the boron concentrations in breast, liver, thigh and bone tissues increased in parallel with the boron addition at increasing levels. Yıldız et al. [36] reported that boric acid (60 mg/kg) added in feed in different farming periods of broiler chickens did not cause a significant effect on growth performance, carcass characteristics and cholesterolemia. In Japanese quails, 40, 80 or $120 \mathrm{mg} / \mathrm{kg}$ boron were added in corn-soybean based feed from 4 different sources (boric acid, anhydrous borax; borax pentahydrate; borax decahydrate) did not significantly affect 0-3 weeks performance characteristics and carcass weight of quails, except for FI, the boron sources used in the ration affected bone thickness-outer diameter significantly and it was found to be significantly higher than all the other sources in the quails fed by boric acid [37]. In the present study, it was determined that the carcass yield was similar between the experimental groups, breast rate decreased significantly depending on dose increase and back and neck rate increased. The highest thigh rate was determined in BA300 and BA500 groups. Similar to present study, Özdemir et al. [14] reported that breast rate decreased in quails by addition of boron. Rossi et al. [8] fed 144 one-day old broiler chicks in the experimental group 1 for 21 days with 0, 5, 40, 80 and 120 ppm boron added feed in two experimental groups and stated that tibias resisted more load compared to the control group. In the experimental group 2, 288 one-day-old chicks were fed with 0, 60,120, 240 and 300 ppm boron added feed for 22 days. Tibia ash percentage was determined at the highest level in the group fed with the 300 ppm boron added ration. Similarly, Cufadar et al. [38] reported that adding $300 \mathrm{mg} / \mathrm{kg}$ boric acid, anhydrous borax, borax pentahydrate and borax decahydrate from different sources into feed had a positive effect on bone tension and bone strength. In the present study, tibia and femur weights and width and length characteristics were not affected by addition of boric acid but the tibia ash level increased from the control to BA300 group and the femur ash level was determined to be at the highest level in the BA300 group. The findings of this study and the aforementioned studies' findings were generally in compliance. Unlike the previous studies, the bone ash level in the BA500 group of this study decreased significantly. This result was considered to be caused by overdose and lead to a toxic effect.

\section{Conclusion}

Both the results of this study and the results of the similar studies revealed that boron affected mineral metabolism but the mentioned effect may change based on the poultry species, genetic structure, the boron level added into feed and its source and the period of feeding by boron. Consequently, it was determined that addition of boric acid into feed did not have a negative effect on the fattening performance and carcass characteristics of quails but it may be useful on their bone quality. The highest ash level was determined in $300 \mathrm{mg} / \mathrm{kg}$ group and the bone ash level decreased in $500 \mathrm{mg} / \mathrm{kg}$ group. It was concluded that adding boric acid at an appropriate level had a positive effect on bone quality as it caused an increase in bone ash level and it may be useful in preventing the skeleton problems observed especially in poultry farming based on rapid live weight increase.

\section{Compliance with ethical standards}

\section{Acknowledgments}

We thank to Firat University Scientific Research Projects (FUBAP-VF.19.09) and Elazı̆̆ Veterinary Control Institute for their supports.

\section{Disclosure of conflict of interest}

The authors declare that there is no conflict of interest in the present study.

\section{Statement of ethical approval}

The approval of Elazığ Veterinary Control Institute Local Ethics Committee (EVKEM: 2020/01) was obtained for the study. 


\section{References}

[1] Bozkurt M, Küçükyılmaz K. The role of boron in poultry nutrition Part II: Compositional and mechanical properties of bone and egg quality. World's Poultry Science Journal. 2015; 71(3): 483-492.

[2] Verstraeten SV, Lanoue L, Keen CL, Oteiza PI. Relevance of lipid polar headgroups on boron-mediated changes in membrane physical properties. Archives of Biochemistry and Biophysics. 2005; 438(1): 103-10.

[3] Helvaci C. Borate deposits: An overview and future forecast with regard to mineral deposits. Journal of Boron. 2017; 2(2): 59 - 70.

[4] Kuru R, Yarat A. Boron and a current overview of its effects on health. Clinical Experimental Health Sciences. 2017; 7: 107-114.

[5] Çimrin T, Demirel M. The using of boron addition in poultry diets. Journal of The Institute of Natural \& Applied Sciences. 2012; 17(1): 46-56.

[6] Demirtaş A. Significance of boron for human nutrition and health. Journal of Agricultural Faculty of Atatürk University. 2010; 41(1): 75-80.

[7] Nielsen FH. Historical and recent aspects of boron in human and animal health. Boron. 2017; 2(3): 153-160.

[8] Rossi AF, Miles RD, Damron BL, Flunker LK. Metabolism and nutrition effects of dietary boron supplementation on broilers. Poultry Science. 1993; 72(11): 2124-2130.

[9] Alencar de Queiroz AA, Abraham GA, Pires Camillo MA, Higa OZ, Silva GS, del Mar Fernandez M, San Roman J. Physicochemical and antimicrobial properties of boron-complexed polyglycerol-chitosan dendrimers. Journal of Biomaterials Science Polymer Edition. 2006; 17(6): 689-707.

[10] Yıldız G, Köksal BH, Sızmaz Ö. Influence of dietary boric acid and liquid humate inclusion on bone characteristics, growth performance and carcass traits in broiler chickens. Archiv für Geflügelkunde. 2013; 77(4): $260-265$.

[11] Dupre JN, Keenan MJ, Hegsted M, Brudevold AM. Effects of dietary boron in rats fed a vitamin d-deficient diet. Environmental Health Perspectives. 1994; 102(7): 55-58.

[12] Yeșilbağ D. The Use of Boron in Animal Nutrition. Uludag University Journal of The Faculty Veterinary Medicine. 2008; 27(1-2): 61-68.

[13] Erisir Z, Simsek UG, Ozcelik M, Baykalir Y, Mutlu SI, Ciftci M. Effects of dietary grape seed on performance and some metabolic assessments in Japanese quail with different plumage colors exposed to heat stress. Revista Brasileira de Zootecnia. 2018; 47: e20170172.

[14] Özdemir G, İnci H, Söğüt B, Şengül T, Yüksel H, Şimşek H, Özdemir A. Effects of dietary boron supplementation on performance and some haematological and antioxidant parameters in Japanese quail exposed to high stocking density. Archiv für Geflügelkunde. 2016; 80.

[15] Waleed Khalid A, Hayani AL. Determining lethal doses of boron in Japanese quails (Coturnix coturnix Japonica) Diets. IOSR Journal of Agriculture and Veterinary Science. 2017; 10(4): 63-67.

[16] NRC. Nutrient Requirements of Poultry: 10th Revised Edition. The National Academies 500 5th Street NW Room KECK 219. 2012.

[17] AOAC. Official Methods of Analysis. 17th Edition, Washington DC Association of Official Agricultural Chemist. 2000.

[18] Leeson S, Summers JD. Nutrition of the chicken. University Books. Guelph, Canada. 2001.

[19] TSI: Turkish Standards Institute, Chicken body meat-shredding, packaging, transportation and preservation rules. TS 5890, Date of acceptance. 18 june 2014.

[20] Sarı M, Çerçi IH. Animal feeds and feeding diseases. Chemical analysis of feeds. Elazı̆g-Tolga-Ofset. 1993; 266279.

[21] SPSS 21. Statistical Packages for the Social Sciences Licensed materials property of IBM corporation (C) copyright IBM corporation and other(s); 1989-2012. International. 2012.

[22] Bialek M, Czauderna M, Krajewska KA, Przybylski W. Selected physiological effects of boron compounds for animals and humans. A review. Journal of Animal and Feed Sciences. 2019; 28: 307-320. 
[23] Olgun 0, Cufadar Y, Yıldız AO. Effects of boron supplementation fed with low calcium to diet on performance and egg quality in molted laying hens. Journal of Animal and Veterinary Advances. 2009; 8(4): 650-654.

[24] Ayasan T, Yurtseven S, Baylan M, Kutlu HR. Effects of boric acid supplementation on egg production and quality of Japanese quails (Coturnix coturnix Japonica). Indian Journal of Animal Sciences. 2011; 81(5): 534-36.

[25] Kocbeker V, Kocbeker V, Bahtiyarca Y, Demirors G. Effect of diets with various calcium and boron levels in prelaying period on growth, bone ash and subsequent performance and shell quality of laying hens. International Journal of Medical Science and Clinical Invention. 2017; 4(11): 3335-3340.

[26] Eren M, Kocaodlu Güçlü B, Uyanık F, Karabulut N. The effects of Diatery Boron Supplementation on Performance, Carcass Composition and Serum Lipids in Japanese Quails. Journal of Animal and Veterinary Advances. 2006; 5(12): 1105-1108.

[27] Sızmaz Ö, Yıldız G. Influence of dietary boric acid and ascorbic acid on performance, egg traits, cholesterol and bone parameters of laying hens. Veterinary Journal of Ankara University. 2016; 63: 151-156.

[28] Eren M, Uyanık F, Küçükersan S. The influence of dietary boron supplementation on egg quality and serum calcium, inorganic phosphorus, magnesium levels and alkaline phosphatase activity in laying Hens. Research in Veterinary Science. 2004; 76(3): 203-210.

[29] Hakan KB, Gultekin Y, Ozge S. Effects of boric acid and humate supplementation on performance and egg quality parameters of laying hens. Brazilian Journal of Poultry Science. 2012; 14(4): 233-304.

[30] Sizmaz O, Yıldız G, Koksal BH. Effects of single or combined dietary supplementation of boric acid and plant extract mixture on egg production, egg quality and blood cholesterolemia in laying hens. Journal ot The Faculty of Veterinary Medicine Kafkas University. 2014; 20(4): 599-604.

[31] Yıldız G, Köksal BH, Sızmaz Ö. Rasyonlara İlave Edilen Maya ve Borik Asidin Broylerlerde Performans, Karkas ve Bazı Kan Parametreleri Üzerine Etkisi. Journal ot The Faculty of Veterinary Medicine Kafkas University. 2011; 17(3): 429-434.

[32] Kara MA. Effects of adding boron to breeder quails diets with different levels of zinc. [Ph.D. dissertation]. The Graduate School of Natural and Applied Science of Konya: Selçuk University. 2013.

[33] Olgun 0, Yazgan 0, Cufadar Y. Effects of boron and copper dietary supplementation in laying hens on egg shell quality, plasma and tibia mineral concentrations and bone biomechanical properties. Revue de Medecine Veterinaire. 2012; 163(7): 335-342.

[34] Mızrak C, Yenice E, Can M, Yıldırım U, Atik Z. Effects of dietary boron on performance, egg production, egg quality and some bone parameters in layer hen. South African Journal of Animal Science. 2010; 40(3): $257-264$.

[35] Wilson JH, Ruszler PL. Long term effects of boron on layer bone strength and production parameters. Journal British Poultry Science. 1998; 39: 11-15.

[36] Yıldız G, Koksal BH, Sizmaz O. Effects of dietary boric acid addition on growth performance, cholesterolemia, some carcass and tibia characteristics in different rearing periods in broiler chickens. Revue de Medecine Veterinaire. 2013; 164(4): 219-224.

[37] Kocbeker V, Bahtiyarca Y. The Effect of ration boron sources and their levels on the carcass weight and bone mineralization in juvenile Japanese quails. Tralleis Agricultural Sciences e-Journal. 2018; 3(2): 250-264.

[38] Cufadar Y, Olgun O, Bahtiyarca Y. Effects of different sources of boron supplementation to diet on egg shell quality and bone characteristics in laying hens. Archiva Zootechnica. 2011; 14: 37-42. 